\title{
Driving the Transition to a Circular Economic Model: A Systematic Review on Drivers and Critical Success Factors in Circular Economy
}

\author{
Davide Aloini ${ }^{1}$, Riccardo Dulmin ${ }^{1}$, Valeria Mininno ${ }^{1}$, Alessandro Stefanini ${ }^{1,2, *}$ and \\ Pierluigi Zerbino ${ }^{1}$ \\ 1 Department of Energy, Systems, Territory and Construction Engineering, University of Pisa, 56126 Pisa, Italy; \\ davide.aloini@unipi.it (D.A.); riccardo.dulmin@unipi.it (R.D.); valeria.mininno@unipi.it (V.M.); \\ pierluigi.zerbino@ing.unipi.it (P.Z.) \\ 2 IN4ACT ERA Chair, School of Economics and Business, Kaunas University of Technology, \\ 44249 Kaunas, Lithuania \\ * Correspondence: alessandro.stefanini@ktu.lt
}

Received: 16 October 2020; Accepted: 17 December 2020; Published: 21 December 2020

\begin{abstract}
The circular economy (CE) is arising as a novel economic system that is restorative by design. In light of its capability to boost sustainable economic development and to cope with environmental challenges, it has recently attracted increasing attention from academics, practitioners, policymakers, and intergovernmental organizations. Despite the wide speculation on this issue, the scientific literature lacks a wide-ranging, systematic, and updated identification and classification of the main drivers and Critical Success Factors of CE initiatives, which appears increasingly necessary to facilitate future scientific work, practical implementations, and policy guidelines. With this aim, this paper develops a systematic literature review by starting with over 400 manuscripts. A final set of 55 selected papers was selected for singling out and classifying drivers and Critical Success Factors in the CE context. The results may provide clear indications for further research, may help business organizations in evaluating CE initiatives, and may guide policy makers in developing and refining CE normative frameworks.
\end{abstract}

Keywords: circular economy; drivers; Critical Success Factors (CSFs); literature review; sustainability

\section{Introduction}

The circular economy (CE) is emerging as a novel approach to boost sustainable economic development and cope with environmental challenges and has recently attracted increasing consideration in discussions on industrial development [1-3].

The traditional and still dominant linear economic model based on extracting-producing-using-discarding materials and energies is unsustainable [1,4]. Although it has been followed throughout the history of humanity, the linear economic model started to assert itself strongly during the industrial revolution in the 18th century, which ignored the environmental limits and the long-term damages caused to the whole world. On the contrary, the CE represents a cyclical and regenerative economic model of production and consumption, which involves reusing, repairing, sharing, refurbishing and recycling existing materials and products for as long as possible [5-7].

Since the growing attention paid to the environmental problem and a more sustainable economic development, the $\mathrm{CE}$ concept and its application have attracted increasing attention from practitioners, academics, policymakers and intergovernmental organizations [1,6-10]. Accordingly, a significant number of studies have focused on the concepts defining the CE [11] and on explaining the relationship between sustainable development and CE [12]. 
In attempts to contribute to this change of model paradigm, a considerable number of scholars have started to explore which drivers may lead the implementations of $C E$ initiatives by business organizations $[13,14]$. The improved awareness and understanding of CE drivers, in fact, may help business organizations in evaluating CE programs and governments/public authorities in providing the right incentives and legislation.

Similarly, numerous studies have been aimed at Critical Success Factors (CSFs), which may pave the way for the implementations of CE initiatives (e.g., Rizos et al., 2016; Sandvik et al., 2019) $[15,16]$. Such factors are the elements-e.g., company capabilities, legislation, financial funding, stakeholder awareness-which enable the implementation of CE business models and are critical in CE projects [17-21]. CSFs strongly influence the degree of initiation, continuation, and success of CE actions and their study may contribute a lot to the "CE transition", which is progressively undertaken by business organizations. This makes the investigation of CFSs a very relevant and current topic from both an academic and a practical perspective [22,23].

Recognizing the importance of both CSFs and drivers concerning the CE initiatives (e.g., Tura et al., 2019; Russel et al., 2020) [24,25], several researchers have begun their investigation. However, the literature in this field appears to be quite fragmented, with most contributions focusing on CSFs or drivers of CE in a particular economic sector and/or business function (e.g., Adams et al., 2017; Agyemang et al., 2019; Notteboom et al., 2020; Garmulewicz et al., 2018; Centobelli et al., 2020) [26-30] or from a specific perspective (e.g., Khan et al., 2020; Kumar and Putnam, 2008) [31,32]. Despite the high number of interesting studies, to the best of our knowledge, the literature lacks a wide-ranging, systematic, and updated identification and classification of the main drivers and CSFs, which appears increasingly necessary to facilitate future scientific works and their classification, to support practical implementations, and to drive policymakers in their CE agenda.

In an attempt to fill this gap, we developed a systematic literature review based on the review protocol by [33]. Starting from over 400 contributions, we selected a final set of 55 manuscripts. Drawing from their in-depth analysis, we singled out a list of CE drivers and CSFs, and we respectively classified them following specific dimensions. Our findings contribute to the scientific literature by providing indications for further research investigating drivers and CSFs in real CE initiatives and simplifying the classification of their results. From a practitioner's viewpoint, this study may also help companies and practitioners in evaluating CE interventions and guiding legislators in the law-making process on CE normative frameworks and the associated sustainability incentives.

The remainder of the paper is structured as follows: Section 2 describes the research design; Section 3 describes and discusses the findings from the literature review; finally, Section 4 depicts the potential directions for future research and concludes the paper.

\section{Materials and Methods}

This research was conducted through a systematic literature review re-adapting the methodology proposed by [33], which has largely been used by other academics (e.g., Savino et al., 2017; Kauppi et al., 2018) [34,35]. Table 1 details the steps followed for this review.

By using the proposed research string, we performed a query on Scopus, which is the largest database of peer-reviewed scientific literature. In addition, ISI Web of Science (WoS) was considered in this research for triangulating the results [36]. We obtained 406 contributions from Scopus and 232 from WoS. Both the Scopus dataset and the WoS dataset were initially refined in Phase 5 (first step) through inclusion/exclusion criteria, reducing the contributions respectively to 308 and 174 . The exclusion of conference papers is due to their commonly lower scientific impact and lower robustness [37]. The two datasets (Scopus and WoS) were subsequently merged into one, considering only once the overlapping papers. The resulting dataset was composed of 316 contributions.

Afterwards, by examining the title, abstract, and keywords, we assessed the appropriateness of the 316 papers with our research objectives and we reduced the number of contributions to 90 (Phase 5 , second step). 
Table 1. Review protocol.

\begin{tabular}{|c|c|c|}
\hline Review Phase & Detail & Outcome \\
\hline $\begin{array}{l}\text { 2. QUERY STRING } \\
\text { DEVELOPMENT }\end{array}$ & $\begin{array}{l}\text { "Circular economy" and "closed-loop supply chain" } \\
\text { were combined through the OR logical operator for } \\
\text { obtaining a broader overview, including also } \\
\text { contributions who use the concept of closed-loop } \\
\text { supply chain. For the same reason, the OR operator } \\
\text { was used for the keywords "antecedent"; } \\
\text { "determinant", "success factor", "enabling factor", } \\
\text { "driver", "enabler". The operator AND was } \\
\text { necessary for isolating only the contributions that } \\
\text { are in the CE field and treat the drivers and/or CSFs. }\end{array}$ & $\begin{array}{l}\text { ("circular economy" OR "closed-loop supply } \\
\text { chain") AND (antecedent OR determinant OR } \\
\text { "success factor" OR "enabling factor" OR driver } \\
\text { OR enabler) }\end{array}$ \\
\hline $\begin{array}{l}\text { 4. SEARCH STRING } \\
\text { AND DATABASE } \\
\text { IDENTIFICATION }\end{array}$ & $\begin{array}{l}\text { We selected Scopus as scientific database because it } \\
\text { is the largest abstract and citation repository of } \\
\text { peer-reviewed literature. To triangulate the results, } \\
\text { ISI Web of Science (WoS) was also considered [36]. } \\
\text { The search in "Title, abstract, keywords" assures a } \\
\text { wide coverage (almost "the maximum" one) of the } \\
\text { results. }\end{array}$ & $\begin{array}{l}\text { Database: Scopus; ISI WoS } \\
\text { The query in Scopus was carried out in } \\
\text { "Title, abstract, keywords". } \\
\text { The query in WoS was carried out in "Title", } \\
\text { "Abstract", "Author Keywords" }\end{array}$ \\
\hline $\begin{array}{l}\text { 6. QUALITY } \\
\text { APPRAISAL OF } \\
\text { ARTICLES IDENTIFIED }\end{array}$ & $\begin{array}{l}\text { The full body of the } 90 \text { papers was evaluated on the } \\
\text { basis of quality criteria (Theory Robustness, } \\
\text { Methodology, Scientific Contribution, Generalizability) } \\
\text { adapted from [33] in line with our research } \\
\text { objective. This method was preferred to } \\
\text { bibliometric metrics, e.g., number of citations, } \\
\text { because the novelty of the CE field. In this way, a } \\
\text { final subset of } 55 \text { papers was obtained. }\end{array}$ & $\begin{array}{l}\text { Input: } 90 \text { papers } \\
\text { Final output: } 55 \text { papers }\end{array}$ \\
\hline $\begin{array}{l}\text { 7. Articles } \\
\text { EVAluation }\end{array}$ & $\begin{array}{l}\text { The selected } 55 \text { papers were reviewed to identify a } \\
\text { list of CE drivers and CSFs and to understand their } \\
\text { potential role. }\end{array}$ & Analysis of the articles \\
\hline
\end{tabular}

Subsequently, the 90 manuscripts were scrutinized (Phase 6) by means of quality criteria (Theory Robustness, Methodology, Scientific Contribution, and Generalizability), which we adapted to our research purpose from [33]. One out of the five criteria proposed by [33] - "Implication for practice" - was not applied in this review because we aimed to include purely theoretical contributions unlike them. The description of the evaluation rules for the quality criteria is reported in Appendix A. 
The 55 papers selected as the final group were analyzed in depth to identify a list of CE drivers and CSFs and understand their potential role (Phase 7).

\section{Results and Discussions}

The 55 selected manuscripts were carefully analyzed, in terms of content and quality, to elicit the CE drivers and CSFs as highlighted by the scientific literature. Sections 3.1 and 3.2 present and discuss the most relevant evidence obtained, respectively, for drivers and for CSFs, and Section 3.3 suggests the managerial implications of this work.

In addition, VOSviewer software, a text-mining software for analyzing the content of titles, keywords, and abstracts, was exploited to identify the most used "keywords" in the field and the connections between them [38,39]. Figure 1 shows the identified keywords and their relationships. The higher the significance and popularity of an item with respect to the other ones, the bigger is the node representing it. The cluster colors of the items indicate clusters of closely associated items. This bibliometric mapping analysis may help researchers find their way around in the considered investigation area.

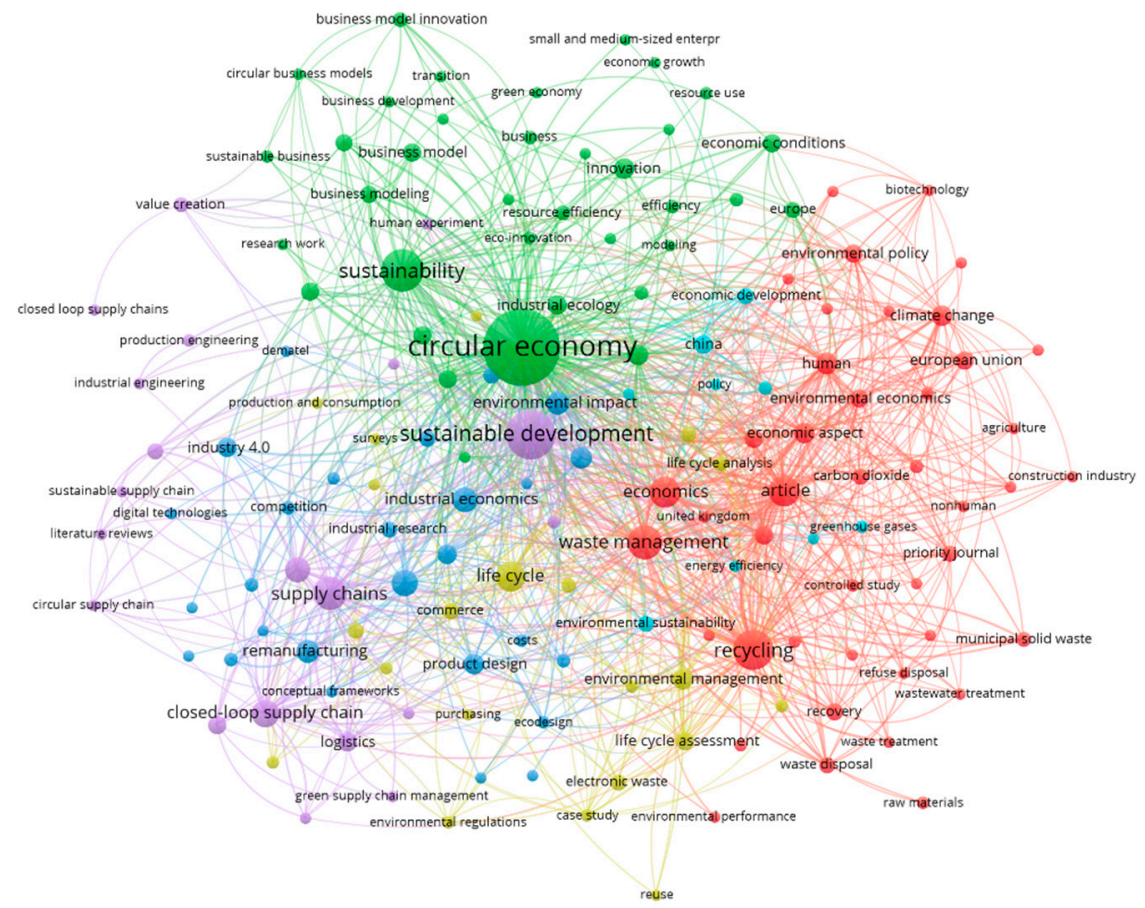

Figure 1. Map of keywords represented through the VOSviewer software.

As expected, the general words related to the research field, such as Circular Economy, Sustainable development, Recycling and Sustainability, are the most frequent keywords, with the term Circular Economy assuming the most preeminent role. It is noteworthy that closed-loop supply chain, although it is used by a specific stream of $C E$ research, is less frequent in the scientific literature with respect to the terms previously reported. Thanks to this representation, scholars may define the most appropriate keywords for searching past research and/or for indexing their own.

\subsection{Drivers}

The analysis of the 55 journal papers enabled the identification of 14 drivers for CE initiatives (Table 2): Legal and regulatory environmental framework; Support; Potential for improving cost efficiency, profitability, revenue streams, and competitiveness; Potential for new business development and innovation; Environmental concerns; Strategical concerns; Skills and capabilities 
for CE; Global pressure; Opportunity for job creation; Consumers' awareness; Communication and collaboration; Supply configuration; Technology for Rs; Information and Communication Technologies. Table 2 describes the drivers and reports the contributions that help to identify them.

Furthermore, to organize and cluster the CE drivers, they were classified in 7 dimensions: Institutional; Economic; Environmental; Organizational; Social; Supply Chain; Technological. These seven dimensions seem to be accepted in the literature, as reported by [24].

Table 2. The drivers of circular economy (CE) initiatives.

\begin{tabular}{|c|c|c|}
\hline Dimension & Driver & Reference \\
\hline \multirow[t]{2}{*}{ INSTITUTIONAL } & $\begin{array}{l}\text { Legal and regulatory environmental framework: policies, } \\
\text { laws, directives, regulations, standard requirements set by } \\
\text { institutions, including extra costs for environmental pollution and } \\
\text { waste (inefficient consumption taxes), regulations on landfill and } \\
\text { end-of-life. }\end{array}$ & {$[5,14,23,24,27,40-44]$} \\
\hline & $\begin{array}{l}\text { Support: tax cuts, refund policies, funding, low-interest loans, } \\
\text { subsidies policies, incentives (e.g., for developing new solutions for } \\
\text { waste collection, for cleaner production, for repairing or renovating } \\
\text { products instead of purchasing new ones). }\end{array}$ & {$[5,10,14,24,41-43,45]$} \\
\hline \multirow[t]{2}{*}{ ECONOMIC } & $\begin{array}{l}\text { Potential for improving cost efficiency, profitability, } \\
\text { revenue streams, and competitiveness: transportation cost } \\
\text { savings, resources' efficient use and recover (Rs, rare materials } \\
\text { included), rising resource demand, higher resources cost, cost } \\
\text { reduction and higher profitability from circular use of resources, } \\
\text { profitability / firm performance / competitiveness, access to funding, } \\
\text { response to competition, reducing dependency from raw materials } \\
\text { import, volatility of resources' price. }\end{array}$ & {$[5,10,13,14,23,24,27,41,43-52]$} \\
\hline & $\begin{array}{l}\text { Potential for new business development and innovation: } \\
\text { new value creation, accessing green, niche or new markets. }\end{array}$ & {$[13,14,24,27,28,46-49]$} \\
\hline ENVIRONMENTAL & $\begin{array}{l}\text { Environmental concerns: climate change and global warming, } \\
\text { overconsumption of energy and resources, scarcity of resources, } \\
\text { environmental safety, resource constraints. }\end{array}$ & {$[10,13,23,24,27,43,45,46,52]$} \\
\hline \multirow[t]{2}{*}{ ORganizational } & $\begin{array}{l}\text { Strategical concerns: brand reputation and social responsibility, } \\
\text { business resiliency, ISO } 14001 \text { certification, corporate strategy for } \\
\text { CE and sustainability, change to a sustainable and competitive } \\
\text { business model, quality of circular products, potential for } \\
\text { differentiation and strengthening. }\end{array}$ & {$[5,14,23,24,27,28,43,46,49,51,53]$} \\
\hline & $\begin{array}{l}\text { Skills and capabilities for CE: training and education for } C E \text {, } \\
\text { development of skills and capabilities for CE, employee involvement } \\
\text { and motivation towards } C E \text { and sustainability. }\end{array}$ & {$[14,24,45,46,53]$} \\
\hline \multirow{3}{*}{ SOCIAL } & $\begin{array}{l}\text { Global pressure: pressure towards greening and healthier } \\
\text { practices from community, competitors, society. }\end{array}$ & {$[10,14,23,24,27,28,45,52,54]$} \\
\hline & Opportunity for job creation & {$[23,24,48,52,54]$} \\
\hline & $\begin{array}{l}\text { Consumers' awareness: environmental awareness, shifting of } \\
\text { consumer preferences (e.g., from ownership of assets to service } \\
\text { models and to sustainable products). }\end{array}$ & {$[5,10,14,23,28,43,45,52]$} \\
\hline \multirow[t]{2}{*}{ Supply Chain } & $\begin{array}{l}\text { Communication and collaboration: environmental } \\
\text { collaboration with customers / suppliers, collaboration or partnership } \\
\text { with stakeholders (organizations, NGOs, government) within the } \\
\text { SC, communication practices and knowledge sharing, potential for } \\
\text { reducing supply dependence and avoiding high and volatile prices, } \\
\text { interconnection capacity (geographical proximity, affinity of } \\
\text { company management to work in an interconnected manner). }\end{array}$ & {$[5,10,14,24,26,27,45-47,50]$} \\
\hline & $\begin{array}{l}\text { Supply configuration: SC integration, management of reverse } \\
\text { network, supply market structure. }\end{array}$ & {$[5,13,14,24,26,46,47]$} \\
\hline \multirow{2}{*}{ Technological } & Technology for Rs & {$[5,13,14,24,27,43-45,50,54]$} \\
\hline & Information and Communication Technologies & {$[13,24,44,54]$} \\
\hline
\end{tabular}


The list of drivers here presented can answer the question "Which factors may encourage an organization to undertake CE actions?".

As demonstrated by the review results, many elements with different natures may push business organizations to embark on CE initiatives. The most important drivers appear to be the Institutional and the economic ones [14], although the social ones are growing in importance. In particular, consumers' awareness and global pressure seem to play a very important role in CE projects (e.g., Moktadir et al., 2018; Salim et al., 2019; Jia et al., 2020; Notteboom et al., 2020) [10,28,45,52]. For instance, [45] showed the high relevance of customer awareness for two leather-processing companies in Bangladesh. The study also discovered that this factor is more important for large-scale companies than smaller ones.

Institutional interventions from governments and other regulatory bodies heavily affect the economic choices of organizations and can really stimulate $C E$ innovations, as well as other actions in the sustainable direction $[24,42,55,56]$. For this reason, institutional support and the legal and regulatory environmental framework may be the real keys to a strong future advancement of CE in the economic world, questioning the linear economic model. For example, [42] show the importance of a proper environmental legislation for municipal waste management companies, underlining how EU legislation -though appropriate public economic incentives-can be one of the major differences between the development level reached by companies in Slovenia and Serbia. While confirming the relevance of an adequate legislation, [10] remarked the preeminent importance of the institutional financial support for implementing a circular business model in the textile industry.

However, the effects of $\mathrm{CE}$ drivers can also highly depend on the specific context involved, e.g., the business sector, the country, and the type of organizations [23]. Although the scientific literature is quite rich, more in-depth investigations of the effects of $C E$ drivers in different business environments are desirable. For example, different aspects can urge companies to apply CE logics in the commodity markets (e.g., paper, iron, and plastic) and in highly specialized markets (e.g., precision electronics, planes, and industrial machines). Likewise, the drivers pushing organizations toward CE initiatives may be very dissimilar between developed countries and underdeveloped ones.

For potential further research, the list of $\mathrm{CE}$ drivers detected in the literature may guide researchers in the study of CE business contexts and/or specific CE projects, preventing the neglect of any possible relevant driver. Moreover, suggestions for future research on CE drivers are reported in Section 4.

\subsection{Critical Success Factors}

The analysis of the 55 journal papers also allowed the identification 13 CSFs for CE initiatives (Table 3): IS and ICT; Rs Technology; Financial support; Financial and economic sustainability; Legal and regulatory environmental framework; Public awareness; Support; CE-oriented business model; Company culture; CE-oriented knowledge and information management; CE-oriented environmental strategy; Coordination and collaboration; Consumer awareness. Table 3 describes each CSF and reports the contributions that help to identify each of them.

To the best of our knowledge, dimensions which classify CSFs of CE had not been identified in the scientific literature. Thus, we elicited through this review the dimensions in which to classify CSFs. Five dimensions were established: Technological; Economic and Financial; Institutional; Strategic; External. The identification of CE dimensions for organizing the CSFs, as reported in Table 3, should be considered a contribution of this work.

The list of CSFs here presented can answer the questions "Which are the enabling factors of CE initiatives?" and "Which capabilities/conditions may support the implementation of CE business models?". 
Table 3. The critical success factors (CSFs) of CE initiatives.

\begin{tabular}{|c|c|c|}
\hline Dimension & Critical Success Factor & Reference \\
\hline \multirow{2}{*}{ TeChNological } & $\begin{array}{l}\text { IS and ICT: includes all digital ICT technologies, digital } \\
\text { intelligence, networks, etc. }\end{array}$ & {$[20,22,25,40,48,57-62]$} \\
\hline & $\begin{array}{l}\text { Rs Technology: technological product and process } \\
\text { innovations to enable and/or improve the Rs. }\end{array}$ & {$[16,26,29,31,32,49,52,60-65]$} \\
\hline \multirow{2}{*}{$\begin{array}{l}\text { ECONOMIC AND } \\
\text { FINANCIAL }\end{array}$} & $\begin{array}{l}\text { Financial support: possibility to access (internal or } \\
\text { external) funding sources. }\end{array}$ & {$[25,31,49,66-68]$} \\
\hline & $\begin{array}{l}\text { Financial and economic sustainability: consistency } \\
\text { between revenue gains/cost savings and necessary } \\
\text { investments. }\end{array}$ & {$[15,18,20,25-27,31,67]$} \\
\hline \multirow{3}{*}{ INSTITUTIONAL } & $\begin{array}{l}\text { Legal and regulatory environmental framework: } \\
\text { national policies; laws and regulations; administrative } \\
\text { enforcement and supervision capacity; other } \\
\text { environmental limits (e.g., landfill practices). }\end{array}$ & {$[18,24,25,31,32,48,52,54,63,65,67-69]$} \\
\hline & $\begin{array}{l}\text { Public awareness: increased public awareness about CE, } \\
\text { sustainability paradigm, and the risk of pollution for } \\
\text { environment (safety and health risks). }\end{array}$ & {$[20,25,26,31,40,41,49,52,63,67,69]$} \\
\hline & $\begin{array}{l}\text { Support: economic support (e.g., loans, subsidies, tax } \\
\text { cuts, incentives), legislative support from public } \\
\text { institutions and other bureaucratic bodies. }\end{array}$ & {$[18,25,26,40,49,52,61,65,66,68]$} \\
\hline \multirow{4}{*}{ Strategic } & $\begin{array}{l}\text { CE-oriented business model: includes } \\
\text { standardization and warranties for recycled products; } \\
\text { greater marketing of upcycled products; development of } \\
\text { higher value secondary market; redistributed } \\
\text { manufacturing; green purchasing; environmental } \\
\text { management system; best practice case studies. }\end{array}$ & {$[22,26,32,52,61-63,65,66,68,70-73]$} \\
\hline & $\begin{array}{l}\text { Company culture: includes trust and openness, } \\
\text { sustainability awareness, environmental culture. }\end{array}$ & {$[15,18,20,24,59,74-76]$} \\
\hline & $\begin{array}{l}\text { CE-oriented knowledge and information } \\
\text { management: four phases of Knowledge Management, } \\
\text { individual and organizational know how, education, skills, } \\
\text { knowledge on environmental consequences, knowledge on } \\
\text { Rs, internal coordination and collaboration, information } \\
\text { on other industries, feasibility studies to analyze potential } \\
\text { synergies, market knowledge, know how on sustainable } \\
\text { technologies. }\end{array}$ & {$[15,18,24,25,40,49,65-69,71,74,75,77,78]$} \\
\hline & $\begin{array}{l}\text { CE-oriented environmental strategy: corporate social } \\
\text { responsibility; CE-oriented vision; policies for CE } \\
\text { practices; commitment and support; green image. }\end{array}$ & {$[15,18,24,27,31,32,52,61,65,67,71,76]$} \\
\hline \multirow[t]{2}{*}{ EXTERNAL } & $\begin{array}{l}\text { Coordination and collaboration: collaboration and } \\
\text { coordination with external stakeholders (e.g., suppliers, } \\
\text { customers, NGOs, regulators, producers, dismantlers, } \\
\text { recyclers, and so on) by networking, information and } \\
\text { knowledge sharing (e.g., on components and disassembly } \\
\text { procedures), conjoint development of products and } \\
\text { capabilities, collaboration on CE targets for Rs, SC } \\
\text { redesign, distributed responsibility for CE implementation } \\
\text { across SC. }\end{array}$ & $\begin{array}{l}{[15,16,18,20,25,32,40,49,52,60-62,65,67,} \\
71,74,76,78-81]\end{array}$ \\
\hline & $\begin{array}{l}\text { Consumer awareness: awareness of the consumers on } \\
C E \text { and sustainability, including their perception towards } \\
C E \text { and used products. }\end{array}$ & {$[31,32,65,66,76]$} \\
\hline
\end{tabular}

This review confirms that many factors with different natures may enable business organizations to succeed in CE initiatives. The most important aspect seems to be the strategic one, as CE interventions usually require a strong and long-term strategy for completing the CE transition $[15,18,71,82]$. For example, the investigation of 61 shows the importance of a long-term strategies, in particular a CE-oriented business model, for the French companies in the electric vehicle battery field. Based on the role in the supply chain, companies should apply different business models, which determine 
their development and market success. In parallel to a strong long-term strategy adopted by the company managers, the awareness of consumers may also play a fundamental role in the success of CE implementations. [65], for example, showed this element, alongside others, in the wood cascading market.

The empirical case studies examined in this work also underline the very significant role played by public institutions in the CE implementations (e.g., Bathia and Kumar Srivastava, 2019; Yu et al., 2014) [14,63]. In particular, two aspect were highly relevant: the economic support-e.g., public subsided loans, non-repayable subsidies, tax cuts, and economic incentives-which public institutions may provide, and the national/regional laws and administrative authorizations, which sometimes can make the implementations of CE initiatives very tricky. Proper institutional interventions, through laws and funds, may create the conditions suitable for enabling numerous CE initiatives, increasing their percentage of success. Without this group of factors, it is difficult for business organizations to succeed in CE action, though some positive experiences are reported [83]. For instance, [63] displayed the importance of institutional support for the development of CE initiatives in North American manufacturing organizations, revealing also the very relevant effects of different state legislations/support in the USA.

As well as for the CE drivers, the CSFs are contingent to the specific context involved, such as the business sector, the country, and the type of organizations [73]. Therefore, a more in-depth examination of CSFs in different business settings is desirable, paying particular attention to the differences between developed and developing countries, given the importance of institutional backing. The products and materials involved also play a very significant role in determining which CSFs have the most impact on the CE initiatives.

Understand better the dynamics behind the CSFs identified and how they can enable the success of $\mathrm{CE}$ interventions in different business environment constitutes an important further development of the scientific literature. In Section 4, suggestions for further research on CSFs are presented.

In addition, thanks to this list of CSFs currently identified by the literature, researchers can explore the potential presence of further enabling factors, maybe some context-specific ones, which have remained neglected until now.

\subsection{Managerial Implications}

The findings of this study also provide interesting managerial implications. The opportunities for business organization to transform their linear economic model into a more circular one are very relevant. However, understanding which $\mathrm{CE}$ interventions may or may not be convenient remains a challenging task. The list of drivers here reported may enable companies and practitioners to focus on the most important aspects in the evaluation of potential CE initiatives, supporting the elaboration of the economic feasibility plan of such interventions [84].

The growing pressure from public opinion on the sustainability issue is urging policymakers and intergovernmental organizations to pay more attention to CE drivers, in particular the institutional one, for favoring a wider application of the CE paradigm [6-8]. With this aim, the comprehension of $C E$ drivers, provided by this paper, may help policymakers to introduce legislation supporting CE practices.

The review also singled out the enablers of CE initiatives through a list of CSFs identified by the scientific literature. In this way, this paper may help organizations in appraising the feasibility of concurrent hypothesized CE actions.

The list of CSFs may also assist business organizations and practitioners in the planning of CE interventions helping to focalize the attention on the most critical factors, which can strongly affect the likelihood of success of such interventions.

Finally, the identification of CSFs may also help policymakers and public institutions in discerning which factors can enable or hinder the implementations of CE paradigms in different business environments and then, it may promote a more encouraging CE legislation. 


\section{Conclusions and Indications for Further Research}

$\mathrm{CE}$ is emerging as a novel approach in the broad context of sustainability. As a more sustainable economy is becoming a priority for the whole world, the transition from a linear to a circular economic model is in the spotlight. In this context, this paper investigates the drivers and CSFs of CE initiatives by developing a systematic literature review. Drawing from a critical analysis of 55 papers, a list of drivers and a list of CSFs was elaborated, following specific dimensions identifiable from past research for their classification.

The literature analysis reveals that more context-specific research evaluating drivers and CSFs in numerous business sector is needed. Our findings also provide researchers with indications for further research on drivers and CSFs in real CE initiatives. Specifically, Tables 4 and 5 present suggestions for future research on drivers and CSFs, respectively.

Relevant managerial directions (Section 3.3) are also pinpointed to support and encourage business organizations toward $\mathrm{CE}$ initiatives and toe guide legislators in law-making processes on the $\mathrm{CE}$ issue and the linked sustainability incentives.

Table 4. Suggestions for further research on CE drivers.

\begin{tabular}{|c|c|}
\hline Driver & Suggestions for Further Research \\
\hline Institutional & $\begin{array}{l}\text { How may institutional regulations and policies facilitate industrial symbiosis? } \\
\text { How may CE institutional support differ between commodity and non-commodity } \\
\text { products? } \\
\text { Which is the actual effectiveness of the different forms of economic-financial incentives } \\
\text { in driving the CE transition? }\end{array}$ \\
\hline Economic & $\begin{array}{l}\text { To which extent may cost savings, higher firm profitability, and better competitiveness } \\
\text { be enabled by CE practices? } \\
\text { How may the potential economic benefit be affected by the market characteristics? } \\
\text { Which new niches or markets may CE enable to develop? }\end{array}$ \\
\hline Environmental & $\begin{array}{l}\text { To which extent may CE practices reduce the exploitation of new resources? } \\
\text { Are environmental concerns an actual priority driver in the firms' agendas? }\end{array}$ \\
\hline Organizational & $\begin{array}{l}\text { How may CE strategies affect product differentiation? } \\
\text { Does the market reward the production of circular products? } \\
\text { How may a firm choose the most appropriate CE practices to pursue its circular } \\
\text { strategy? } \\
\text { What are the new professional figures needed in circular markets? And which skills } \\
\text { should they possess? }\end{array}$ \\
\hline Social & $\begin{array}{l}\text { Which may be the impact of the CE transition on job turnover and on the creation of } \\
\text { new job roles? } \\
\text { Which are the most effective means for a firm to communicate its CE values? } \\
\text { How much are the new servitization business models adopted by the firms and } \\
\text { appreciated by the customers? }\end{array}$ \\
\hline Supply Chain & $\begin{array}{l}\text { Which is the actual impact of the new CE actors (e.g., CE service brokers, decomposers, } \\
\text { scavengers) on firms SC performances? } \\
\text { How may forward SC issues (e.g., demand forecasting, bullwhip effect) affect reverse } \\
\text { SCs? And how to cope with them? }\end{array}$ \\
\hline Technological & $\begin{array}{l}\text { How may collaborative technologies support the development of a CE strategy [85]? } \\
\text { How may data integrity be granted in circular ecosystems? }\end{array}$ \\
\hline
\end{tabular}


Table 5. Suggestions for further research on CE CSFs.

\begin{tabular}{|c|c|}
\hline CSF & Suggestions for Further Research \\
\hline Technological & $\begin{array}{l}\text { Which role may Distributed Ledger Technologies play in circular ecosystems? } \\
\text { How may Enterprise Systems embed CE management processes? } \\
\text { Which may be the most effective and innovative ICT to leverage in CE ecosystems? } \\
\text { To which extent may technology-enabled process innovations contribute to the success of a } \\
\text { CE strategy? }\end{array}$ \\
\hline $\begin{array}{l}\text { Economic and } \\
\text { Financial }\end{array}$ & $\begin{array}{l}\text { Which founding sources should be more accessible to stimulate the transition towards CE? } \\
\text { How may Closed-Loop Supply Chains benefit from collective funding initiatives, such as } \\
\text { crowdfunding? }\end{array}$ \\
\hline Institutional & $\begin{array}{l}\text { How may institutions support the regulation of new actors, such as scavengers, } \\
\text { decomposers, and dismantlers? } \\
\text { Which may be the most effective channels to raise public awareness concerning CE? } \\
\text { Which may be the main legislative voids to fill for facilitating the implementation of } \\
\text { CE strategies? }\end{array}$ \\
\hline Strategic & $\begin{array}{l}\text { Which may be the most effective and efficient strategies to enhance competitiveness in the } \\
\text { secondary raw materials market? } \\
\text { What may be the most relevant hurdles to CE-oriented change management activities? } \\
\text { How should firms educate, train, and empower their human resources to catalyze the } \\
\text { sustainable circular transition? } \\
\text { Should the organizational structure be redesigned to spread CE-oriented commitment } \\
\text { across all the firm's levels? }\end{array}$ \\
\hline External & $\begin{array}{l}\text { Which are the main CE collaborative patterns in Closed-Loop Supply Chains? And how do } \\
\text { they differ among different markets? } \\
\text { What may be the risks associated with the distributed responsibility for CE } \\
\text { implementation across the SC? } \\
\text { Which may be the benefits and drawbacks of integrating dismantlers and recyclers into a } \\
\text { firm's own business? } \\
\text { Which may be the most effective and efficient knowledge sharing practices in } \\
\text { CE ecosystems? }\end{array}$ \\
\hline
\end{tabular}

Author Contributions: Conceptualization, D.A., R.D., V.M., A.S. and P.Z.; Methodology, D.A., R.D., V.M., A.S. and P.Z.; Formal Analysis, D.A., R.D., V.M., A.S. and P.Z.; Investigation, D.A., R.D., V.M., A.S. and P.Z.; Writing-Original Draft Preparation, D.A., R.D., V.M., A.S. and P.Z.; Writing-Review and Editing, D.A., R.D., V.M., A.S. and P.Z.; Supervision, D.A., R.D., V.M., A.S. and P.Z. All authors have read and agreed to the published version of the manuscript.

Funding: This research received no external funding.

Conflicts of Interest: The authors declare no conflict of interest.

\section{Appendix A}

All the 90 papers were evaluated based on four quality criteria adapted to our research purpose from [33]: Theory Robustness, Methodology, Scientific Contribution, and Generalizability. Each paper obtained a score from 0 to 3 for each criterion as proposed by [33]. Afterwards, the papers were selected through specific rules, as reported by Table A1. Following these rules, a final subset of 55 papers was obtained.

Table A1. Rules for selecting the papers based on the quality criteria.

\begin{tabular}{ccc}
\hline Rule & Description & Justification \\
\hline RuLE 1 & $\begin{array}{c}\text { Scientific contribution, } \\
\text { Theory robustness } \geq 2\end{array}$ & $\begin{array}{c}\text { Selection of papers with a strong contribution and with } \\
\text { sound foundations }\end{array}$ \\
\hline RuLE 2 & $\begin{array}{c}\text { Generalizability and } \\
\text { Methodology } \geq 1\end{array}$ & $\begin{array}{c}\text { The generalizability of several research in the field are low } \\
\text { because numerous CE drivers and CSFs tend to be } \\
\text { context-specific; since the fragmentation of the CE research field, } \\
\text { research design turn to be very specific; }\end{array}$ \\
\hline RULE 3 & Total evaluation $\geq 8$ & To guarantee a sufficient overall quality for the selected papers \\
\hline
\end{tabular}




\section{References}

1. Korhonen, J.; Nuur, C.; Feldmann, A.; Birkie, S.E. Circular economy as an essentially contested concept. J. Clean. Prod. 2018, 175, 544-552. [CrossRef]

2. Bradley, R.; Jawahir, I.S.; Badurdeen, F.; Rouch, K. A total life cycle cost model (TLCCM) for the circular economy and its application to post-recovery resource allocation. Resour. Conserv. Recycl. 2018, 135, 141-149. [CrossRef]

3. Gupta, S.; Chen, H.; Hazen, B.T.; Kaur, S.; Gonzalez, E.D.S. Circular economy and big data analytics: A stakeholder perspective. Technol. Forecast. Soc. Chang. 2019, 144, 466-474. [CrossRef]

4. Frosch, R.A.; Gallopoulos, N.E. Strategies for Manufacturing. Sci. Am. 1989, 261, 144-152. [CrossRef]

5. Prieto-Sandoval, V.; Jaca, C.; Ormazabal, M. Towards a consensus on the circular economy. J. Clean. Prod. 2018, 179, 605-615. [CrossRef]

6. European Commission (EC). Closing the Loop-An EU Action Plan for the Circular Economy. Available online: https://eur-lex.europa.eu/resource.html?uri=cellar:8a8ef5e8-99a0-11e5-b3b7-01aa75ed71a1.0012.02/ DOC_1\&format=PDF (accessed on 1 August 2020).

7. European Commission (EC). A New Circular Economy Action Plan for a Cleaner and More Competitive Europe. 2020. Available online: https://eur-lex.europa.eu/resource.html?uri=cellar:9903b325-6388-11eab735-01aa75ed71a1.0017.02/DOC_1\&format=PDF (accessed on 1 August 2020).

8. Central Committee of the Communist Party of China. The 13th five-year plan for Economic and Social Development of the People's Republic of China (2016-2020). 2016. Available online: https://en.ndrc.gov.cn/ policyrelease_8233/201612/P020191101482242850325.pdf (accessed on 3 August 2020).

9. Paletta, A.; Filho, W.L.; Balogun, A.-L.; Foschi, E.; Bonoli, A. Barriers and challenges to plastics valorisation in the context of a circular economy: Case studies from Italy. J. Clean. Prod. 2019, 241, 118149. [CrossRef]

10. Jia, F.; Yin, S.; Chen, L.; Chen, X. The circular economy in the textile and apparel industry: A systematic literature review. J. Clean. Prod. 2020, 259, 120728. [CrossRef]

11. Kirchherr, J.; Reike, D.; Hekkert, M. Conceptualizing the circular economy: An analysis of 114 definitions. Resour. Conserv. Recycl. 2017, 127, 221-232. [CrossRef]

12. Geissdoerfer, M.; Savaget, P.; Bocken, N.M.; Hultink, E.J. The Circular Economy-A new sustainability paradigm? J. Clean. Prod. 2017, 143, 757-768. [CrossRef]

13. Ghisellini, P.; Cialani, C.; Ulgiati, S. A review on circular economy: The expected transition to a balanced interplay of environmental and economic systems. J. Clean. Prod. 2016, 114, 11-32. [CrossRef]

14. Dijkstra, H.; Van Beukering, P.; Brouwer, R. Business models and sustainable plastic management: A systematic review of the literature. J. Clean. Prod. 2020, 258, 120967. [CrossRef]

15. Rizos, V.; Behrens, A.; Van Der Gaast, W.; Hofman, E.; Ioannou, A.; Kafyeke, T.; Flamos, A.; Rinaldi, R.; Papadelis, S.; Hirschnitz-Garbers, M.; et al. Implementation of Circular Economy Business Models by Small and Medium-Sized Enterprises (SMEs): Barriers and Enablers. Sustainability 2016, 8, 1212. [CrossRef]

16. Sandvik, I.M.; Stubbs, W. Circular fashion supply chain through textile-to-textile recycling. J. Fash. Mark. Manag. Int. J. 2019, 23, 366-381. [CrossRef]

17. Wynstra, F.; Axelsson, B.; Van Weele, A. Driving and enabling factors for purchasing involvement in product development. Eur. J. Purch. Supply Manag. 2000, 6, 129-141. [CrossRef]

18. De Mattos, C.A.; De Albuquerque, T.L.M. Enabling Factors and Strategies for the Transition Toward a Circular Economy (CE). Sustainability 2018, 10, 4628. [CrossRef]

19. Aloini, D.; Dulmin, R.; Mininno, V.; Ponticelli, S. Key antecedents and practices for Supply Chain Management adoption in project contexts. Int. J. Proj. Manag. 2015, 33, 1301-1316. [CrossRef]

20. Hussain, M.; Malik, M. Organizational enablers for circular economy in the context of sustainable supply chain management. J. Clean. Prod. 2020, 256, 120375. [CrossRef]

21. Cammarano, A.; Michelino, F.; Caputo, M. Open innovation practices for knowledge acquisition and their effects on innovation output. Technol. Anal. Strat. Manag. 2019, 31, 1297-1313. [CrossRef]

22. Moreno, M.; Court, R.; Wright, M.; Charnley, F. Opportunities for redistributed manufacturing and digital intelligence as enablers of a circular economy. Int. J. Sustain. Eng. 2018, 12, 77-94. [CrossRef]

23. Govindan, K.; Hasanagic, M. A systematic review on drivers, barriers, and practices towards circular economy: A supply chain perspective. Int. J. Prod. Res. 2018, 56, 278-311. [CrossRef] 
24. Tura, N.; Hanski, J.; Ahola, T.; Ståhle, M.; Piiparinen, S.; Valkokari, P. Unlocking circular business: A framework of barriers and drivers. J. Clean. Prod. 2019, 212, 90-98. [CrossRef]

25. Russell, M.; Gianoli, A.; Grafakos, S. Getting the ball rolling: An exploration of the drivers and barriers towards the implementation of bottom-up circular economy initiatives in Amsterdam and Rotterdam. J. Environ. Plan. Manag. 2019, 63, 1903-1926. [CrossRef]

26. Adams, K.T.; Osmani, M.; Thorpe, T.; Thornback, J. Circular economy in construction: Current awareness, challenges and enablers. In Proceedings of the Institution of Civil Engineers-Waste and Resource Management; Thomas Telford Ltd.: London, UK, 2017; Volume 170, pp. 15-24. [CrossRef]

27. Agyemang, M.; Kusi-Sarpong, S.; Khan, S.A.; Mani, V.; Rehman, S.T.; Kusi-Sarpong, H. Drivers and barriers to circular economy implementation. Manag. Decis. 2019, 57, 971-994. [CrossRef]

28. Notteboom, T.; Van Der Lugt, L.; Van Saase, N.; Sel, S.; Neyens, K. The Role of Seaports in Green Supply Chain Management: Initiatives, Attitudes, and Perspectives in Rotterdam, Antwerp, North Sea Port, and Zeebrugge. Sustainability 2020, 12, 1688. [CrossRef]

29. Garmulewicz, A.; Holweg, M.; Veldhuis, H.; Yang, A. Disruptive Technology as an Enabler of the Circular Economy: What Potential Does 3D Printing Hold? Calif. Manag. Rev. 2018, 60, 112-132. [CrossRef]

30. Centobelli, P.; Cerchione, R.; Chiaroni, D.; Del Vecchio, P.; Urbinati, A. Designing business models in circular economy: A systematic literature review and research agenda. Bus. Strat. Environ. 2020, 29, 1734-1749. [CrossRef]

31. Khan, S.; Maqbool, A.; Haleem, A.; Khan, M.I. Analyzing critical success factors for a successful transition towards circular economy through DANP approach. Manag. Environ. Qual. Int. J. 2020, 31, 505-529. [CrossRef]

32. Kumar, S.; Putnam, V. Cradle to cradle: Reverse logistics strategies and opportunities across three industry sectors. Int. J. Prod. Econ. 2008, 115, 305-315. [CrossRef]

33. Pittaway, L.; Robertson, M.; Munir, K.; Denyer, D.; Neely, A. Networking and innovation: A systematic review of the evidence. Int. J. Manag. Rev. 2004, 137-168. [CrossRef]

34. Savino, T.; Petruzzelli, A.M.; Albino, V. Search and Recombination Process to Innovate: A Review of the Empirical Evidence and a Research Agenda. Int. J. Manag. Rev. 2017, 19, 54-75. [CrossRef]

35. Kauppi, K.; Salmi, A.; You, W. Sourcing from Africa: A Systematic Review and a Research Agenda. Int. J. Manag. Rev. 2018, 20, 627-650. [CrossRef]

36. Falagas, M.E.; Pitsouni, E.I.; Malietzis, G.A.; Pappas, G. Comparison of PubMed, Scopus, Web of Science, and Google Scholar: Strengths and weaknesses. FASEB J. 2008, 22, 338-342. [CrossRef] [PubMed]

37. Lisée, C.; Larivière, V. Archambault, Éric Conference proceedings as a source of scientific information: A bibliometric analysis. J. Am. Soc. Inf. Sci. Technol. 2008, 59, 1776-1784. [CrossRef]

38. Perianes-Rodriguez, A.; Waltman, L.; Van Eck, N.J. Constructing bibliometric networks: A comparison between full and fractional counting. J. Inf. 2016, 10, 1178-1195. [CrossRef]

39. Shah, S.H.H.; Lei, S.; Ali, M.; Doronin, D.; Hussain, S.T. Prosumption: Bibliometric analysis using HistCite and VOSviewer. Kybernetes 2019. [CrossRef]

40. Yu, C.; De Jong, M.; Dijkema, G.P. Process analysis of eco-industrial park development-The case of Tianjin, China. J. Clean. Prod. 2014, 64, 464-477. [CrossRef]

41. Yu, F.; Han, F.; Cui, Z. Evolution of industrial symbiosis in an eco-industrial park in China. J. Clean. Prod. 2015, 87, 339-347. [CrossRef]

42. Ilić, M.; Nikolić, M. Drivers for development of circular economy-A case study of Serbia. Habitat Int. 2016, 56, 191-200. [CrossRef]

43. De Jesus, A.; Mendonça, S. Lost in transition? Drivers and barriers in the eco-innovation road to the circular economy. Ecol. Econ. 2018, 145, 75-89. [CrossRef]

44. Jabbour, C.J.C.; Fiorini, P.D.C.; Wong, C.W.; Jugend, D.; Jabbour, A.B.L.D.S.; Seles, B.M.R.P.; Pinheiro, M.A.P.; Da Silva, H.M.R. First-mover firms in the transition towards the sharing economy in metallic natural resource-intensive industries: Implications for the circular economy and emerging industry 4.0 technologies. Resour. Policy 2020, 66, 101596. [CrossRef]

45. Moktadir, A.; Rahman, T.; Rahman, H.; Ali, S.M.; Paul, S.K. Drivers to sustainable manufacturing practices and circular economy: A perspective of leather industries in Bangladesh. J. Clean. Prod. 2018, 174, 1366-1380. [CrossRef] 
46. Linder, M.; Williander, M. Circular business model innovation: Inherent uncertainties. Bus. Strategy Environ. 2017, 26, 182-196. [CrossRef]

47. Pitt, J.; Heinemeyer, C. Introducing ideas of a circular economy. In Environment, Ethics and Cultures; Brill Sense: Leiden, The Netherlands, 2015; pp. 245-260.

48. Riisgaard, H.; Mosgaard, M.; Zacho, K.O. Local Circles in a Circular Economy-The Case of Smartphone Repair in Denmark. Eur. J. Sustain. Dev. 2016, 5, 109-123. [CrossRef]

49. Masi, D.; Day, S.; Godsell, J. Supply Chain Configurations in the Circular Economy: A Systematic Literature Review. Sustainability 2017, 9, 1602. [CrossRef]

50. Cramer, J.M. Key Drivers for High-Grade Recycling under Constrained Conditions. Recycling 2018, 3, 16. [CrossRef]

51. Gaur, J.; Mani, V. Antecedents of closed-loop supply chain in emerging economies: A conceptual framework using stakeholder's perspective. Resour. Conserv. Recycl. 2018, 139, 219-227. [CrossRef]

52. Salim, H.K.; Stewart, R.A.; Sahin, O.; Dudley, M. Drivers, barriers and enablers to end-of-life management of solar photovoltaic and battery energy storage systems: A systematic literature review. J. Clean. Prod. 2019, 211, 537-554. [CrossRef]

53. Bocken, N.M.; De Pauw, I.; Bakker, C.; Van Der Grinten, B. Product design and business model strategies for a circular economy. J. Ind. Prod. Eng. 2016, 33, 308-320. [CrossRef]

54. Mathews, J.A.; Tan, H. Progress toward a circular economy in China: The drivers (and inhibitors) of eco-industrial initiative. J. Ind. Ecol. 2011, 15, 435-457. [CrossRef]

55. Michelino, F.; Cammarano, A.; Celone, A.; Caputo, M. The Linkage between Sustainability and Innovation Performance in IT Hardware Sector. Sustainability 2019, 11, 4275. [CrossRef]

56. Cammarano, A.; Caputo, M.; Lamberti, E.; Michelino, F. R\&D Collaboration Strategies for Innovation: An Empirical Study Through Social Network Analysis. Int. J. Innov. Technol. Manag. 2017, 14, 1740001. [CrossRef]

57. Koppius, O.; Özdemir-Akyıldırım, Ö.; Laan, E.V.D. Business value from closed-loop supply chains. Int. J. Supply Chain Manag. 2014, 3, 107-120.

58. Bressanelli, G.; Adrodegari, F.; Perona, M.; Saccani, N. Exploring How Usage-Focused Business Models Enable Circular Economy through Digital Technologies. Sustainability 2018, 10, 639. [CrossRef]

59. Flygansvær, B.; Dahlstrom, R.; Nygaard, A. Exploring the pursuit of sustainability in reverse supply chains for electronics. J. Clean. Prod. 2018, 189, 472-484. [CrossRef]

60. Garcia-Muiña, F.E.; González-Sánchez, R.; Ferrari, A.M.; Volpi, L.; Pini, M.; Siligardi, C.; Settembre-Blundo, D. Identifying the Equilibrium Point between Sustainability Goals and Circular Economy Practices in an Industry 4.0 Manufacturing Context Using Eco-Design. Soc. Sci. 2019, 8, 241. [CrossRef]

61. Alamerew, Y.A.; Brissaud, D. Modelling reverse supply chain through system dynamics for realizing the transition towards the circular economy: A case study on electric vehicle batteries. J. Clean. Prod. 2020, 254, 120025. [CrossRef]

62. Julianelli, V.; Caiado, R.G.G.; Scavarda, L.F.; Cruz, S.P.D.M.F. Interplay between reverse logistics and circular economy: Critical success factors-based taxonomy and framework. Resour. Conserv. Recycl. 2020, 158, 104784. [CrossRef]

63. Bhatia, M.S.; Srivastava, R.K. Antecedents of implementation success in closed-loop supply chain: An empirical investigation. Int. J. Prod. Res. 2019, 57, 7344-7360. [CrossRef]

64. Despeisse, M.; Baumers, M.; Brown, P.; Charnley, F.; Ford, S.; Garmulewicz, A.; Knowles, S.; Minshall, T.; Mortara, L.; Reed-Tsochas, F.; et al. Unlocking value for a circular economy through 3D printing: A research agenda. Technol. Forecast. Soc. Chang. 2017, 115, 75-84. [CrossRef]

65. Jarre, M.; Petit-Boix, A.; Priefer, C.; Meyer, R.; Leipold, S. Transforming the bio-based sector towards a circular economy-What can we learn from wood cascading? For. Policy Econ. 2020, 110, 101872. [CrossRef]

66. Singh, J.; Sung, K.; Cooper, T.; West, K.; Mont, O. Challenges and opportunities for scaling up upcycling businesses-The case of textile and wood upcycling businesses in the UK. Resour. Conserv. Recycl. 2019, 150, 104439. [CrossRef]

67. Gong, Y.; Putnam, E.; You, W.; Zhao, C. Investigation into circular economy of plastics: The case of the UK fast moving consumer goods industry. J. Clean. Prod. 2020, 244, 118941. [CrossRef]

68. Mura, M.; Longo, M.; Zanni, S. Circular economy in Italian SMEs: A multi-method study. J. Clean. Prod. 2020, 245, 118821. [CrossRef] 
69. Matus, K.J.M.; Xiao, X.; Zimmerman, J.B. Green chemistry and green engineering in China: Drivers, policies and barriers to innovation. J. Clean. Prod. 2012, 32, 193-203. [CrossRef]

70. Lewandowski, M. Designing the Business Models for Circular Economy-Towards the Conceptual Framework. Sustainability 2016, 8, 43. [CrossRef]

71. Sharma, M.; Joshi, S.; Kumar, A. Assessing enablers of e-waste management in circular economy using DEMATEL method: An Indian perspective. Environ. Sci. Pollut. Res. 2020, 27, 13325-13338. [CrossRef]

72. Van Buren, N.; Demmers, M.; Van Der Heijden, R.; Witlox, F. Towards a Circular Economy: The Role of Dutch Logistics Industries and Governments. Sustainability 2016, 8, 647. [CrossRef]

73. Henry, M.; Bauwens, T.; Hekkert, M.; Kirchherr, J. A typology of circular start-ups: An Analysis of 128 circular business models. J. Clean. Prod. 2020, 245, 118528. [CrossRef]

74. Walls, J.L.; Paquin, R.L. Organizational perspectives of industrial symbiosis: A review and synthesis. Organ. Environ. 2015, 28, 32-53. [CrossRef]

75. Sehnem, S.; Jabbour, C.J.C.; Pereira, S.C.F.; Jabbour, A.B.L.D.S. Improving sustainable supply chains performance through operational excellence: Circular economy approach. Resour. Conserv. Recycl. 2019, 149, 236-248. [CrossRef]

76. Singhal, D.; Jena, S.K.; Tripathy, S. Factors influencing the purchase intention of consumers towards remanufactured products: A systematic review and meta-analysis. Int. J. Prod. Res. 2019, 57, 7289-7299. [CrossRef]

77. Miemczyk, J.; Howard, M.; Johnsen, T.E. Dynamic development and execution of closed-loop supply chains: A natural resource-based view. Supply Chain Manag. Int. J. 2016, 21, 453-469. [CrossRef]

78. Prosman, E.-J.; Waehrens, B.V.; Liotta, G. Closing Global Material Loops: Initial Insights into Firm-Level Challenges. J. Ind. Ecol. 2017, 21, 641-650. [CrossRef]

79. Mishra, J.L.; Chiwenga, K.D.; Ali, K. Collaboration as an enabler for circular economy: A case study of a developing country. Manag. Decis. 2019. [CrossRef]

80. Nußholz, J.L. A circular business model mapping tool for creating value from prolonged product lifetime and closed material loops. J. Clean. Prod. 2018, 197, 185-194. [CrossRef]

81. Cantele, S.; Moggi, S.; Campedelli, B. Spreading Sustainability Innovation through the Co-Evolution of Sustainable Business Models and Partnerships. Sustainability 2020, 12, 1190. [CrossRef]

82. Michelino, F.; Cammarano, A.; Lamberti, E.; Caputo, M. Measurement of open innovation through intellectual capital flows: Framework and application. Int. J. Intell. Enterp. 2014, 2, 213. [CrossRef]

83. Lahane, S.; Kant, R.; Shankar, R. Circular supply chain management: A state-of-art review and future opportunities. J. Clean. Prod. 2020, 258, 120859. [CrossRef]

84. Michelino, F.; Lamberti, E.; Cammarano, A.; Caputo, M. Open models for innovation: An accounting-based perspective. Int. J. Technol. Manag. 2015, 68, 99. [CrossRef]

85. Yang, S.R.; MR, A.R.; Kaminski, J.; Pepin, H. Opportunities for Industry 4.0 to Support Remanufacturing. Appl. Sci. 2018, 8, 1177. [CrossRef]

Publisher's Note: MDPI stays neutral with regard to jurisdictional claims in published maps and institutional affiliations.

(C) 2020 by the authors. Licensee MDPI, Basel, Switzerland. This article is an open access article distributed under the terms and conditions of the Creative Commons Attribution (CC BY) license (http://creativecommons.org/licenses/by/4.0/). 